\title{
Structural Shifts and Reform of the Agrarian Sector of the Russian Economy under the Conditions of the Import Substitution Policy
}

Irina V. Zhupley, ${ }^{\dagger}$ Tatiana A. Potenko, ${ }^{\top}$ Sergey V. Gubarkov, ${ }^{+*}$ Natalia A. Tretyak ${ }^{\dagger}$ and Roman A. Grafov' $^{\prime}$

\section{Abstract}

The paper deals with international and Russian structural problems in agriculture. The objective of the paper is the research of structural changes in the agricultural sector of Russia and their change under the effect of the 'sectoral' sanctions and the food commodity import substitution policy. The theoretical base for this paper has become the works of the scientists dealing with the problems of the structural economic development at the macro level. The nature of the structural shifts in the Russian agrarian sector was discovered, as well as the disproportions in development of different countries, especially those producing the threat to the food supply security and thus the economic safety of the states. The authors have studied the structure of the main commodity groups influencing the solution of the import substitution problem; computed the basic indicators of the corresponding structural shifts; and highlighted the most efficient groups of the agricultural producers. Also, the paper represents the econometric model of the structural shifts and the assessment of the level of self-sufficiency with agricultural production in Russia. The research has been conducted based on the methodology of structural analysis represented in the scientific pursuits of the foreign and national scientists. It also contains the conclusion about the necessity of strengthening the structural policy in the animal husbandry. In particular, import substitution in the sub-branches of the agriculture and food industry should be combined with the export development in the other spheres (based on the methodology of full and efficient use of the available agricultural potential).

Keywords: Agriculture, Agricultural Structure, Import Substitution, Economic Sanctions, Agricultural Organisations, Peasant (farm) Enterprises.

\footnotetext{
${ }^{\dagger}$ Department of Economics, Ussuriysk Branch of the Far Eastern Federal University, 692508, 35 Nekrasov Street, Ussuriysk, Russian Federation.

'Department of Economics and Organization of Agri-industrial Complex, Primorsky Scientific Research Institute of Agriculture, 692539, 30 Volozhenin Street, Ussuriysk, Russian Federation

'Department of Management and Agribusiness, Kemerovo State Agricultural Institute, 650056, 5 Markovtsev Street, Kemerovo, Russian Federation.

${ }^{*}$ Corresponding Author: Email: gsv20031973@mail.ru

(C)2018 Zhupley et al. This is an Open Access article distributed under the terms of the Creative Commons Attribution License (http://creativecommons.org/licenses/by/2.0), which permits unrestricted use, distribution, and reproduction in any medium, provided the original work is properly cited.
} 


\section{Introduction}

Agriculture is the most important element of the economic system in any country because the provision of the population with high quality environmentally safe food complying with the medical and biological standards is a vital task of any government (Baynova et al., 2016; Povorina et al., 2017).

The problem of the food commodity availability for a great part of the world population is unfortunately rather acute now. The reasons of such a situation are the growth of the Earth population (approximately by 85 million people per year (Countrymeters, 2017), and the world agricultural crises, as well as various financial disturbances and geopolitical instability (Naumenkova, 2015).

For Russia with its significant natural resources, this problem is also very acute. Paradoxically, the state with $37 \%$ of the global agricultural lands, $52 \%$ of the world black soil (Korobeynikov, 2010), and 20\% of the freshwater resources of Earth (Danilov-Danilyan and Khranovich, 2010), is unproductive in agriculture. There are many reasons for such a situation. One of the most important, in our opinion, is the irrational agricultural structure (including the territorial and industrial structure) and negative structural shifts in the agricultural sector of the Russian Federation.

\section{Literature Review}

In the 21st century, the disproportions in development of different countries have been actively studied, especially those producing the threat to the food supply security and thus the economic safety of the states (Arbuzov, 2017). The structural reforms, according to $\mathrm{K}$. Natuhara (2008), may become a powerful tool for economic recovery and growth.

High prices of the food provoke anxiety throughout the world. For example, to produce a kilo of beef, a Canadian farmer requires about seven kilos of corn. Thus, the increase of the corn price leads to the rise in the beef price. In the US, the increase in the corn price leads to the decrease in the wildlife population and the increase in the corn farming, thus contributing to the emergence of the structural problem of corn over-production and deficiency of meat.

At the same time, the demand for food constantly increases. The rise in the meat consumption over the last ten years in the developing countries is averagely equal to $5 \%$ per year (versus half a per cent in the developed economies). Particularly, in the PRC one may observe the annual increase in meat consumption per capita equal to two kilos (Bennett, 2008).

Russia is characterised both by the mentioned structural problems and the specific ones caused by the dissolution of the USSR and the break of the territorial, cross-sectional and economic connections established by that time.

The structural misbalances and disproportions were inherited by the modern Russian agrarian sphere from the rigidly regulated economy of the Soviet Union (Aganbegyan et al., 2013), and multiply increased as a result of the 'shock' reform of the late twentieth century. Even now despite the growth of some indicators of the agriculture, it has not reached the level of the period before the reforms.

The nature of the structural shifts in the Russian agrarian sector could not but have been affected the economic sanctions effective till present, which were imposed by several states of Western Europe in 2014. The import substitution policy and the 'import substitution road map' as the countermeasures of the RF (alongside with the retaliatory sanctions) against the speculative actions of the states supporting the sanctions is another vital stimulus for change in the direction of the structural changes in the Russian agriculture. As noted by Ushachev (2016), "the current problems of import substitution are the most widely discussed both in the legislativeexecutive bodies and in the public organisations of the country, not mentioning the business".

A series of papers (Manturov et al., 2016; Pavlov and Kaukin, 2017; Tsukhlo, 2016) study the influence of the 'sectoral' sanctions of the EU and the US on the value of the Russian 
import in the context of the import substitution policy, but predominantly for the branches of the industry.

The structural changes in the Russian agrarian sector under the new post-sanction conditions, as well as the structural problems in the agricultural sphere, are considered in the papers of (Osipov et al., 2018; Zhupley et al., 2017).

The paper (Schmidt and Gu, 2017) notes that the modern stage of the research is characterized by a rather deep study of the theoretical and methodological problems in the analysis and assessment of the structural changes in the agrarian economy, social and economic consequences of the structural shifts under the post-industrial conditions (Ryabova, 2012).

One should pay attention to the paper (Prilepsky, 2017), showing that in the Russian non-raw-material economy sector (first of all in the agriculture) according to so-called 'strong import substitution attribute' (reflecting the dynamics of the national produce supply to the internal market of the country), the regularities formed by now are to a greater extent not favourable enough.

Thus, in the modern conditions, the research of the structural shifts in the agricultural sector of the RF influenced by the implementation of the food commodity import substitution program is relevant.

\section{Methodology}

The main task of the paper is research of structural changes in the agricultural sector of Russia and their change under the effect of the 'sectoral' sanctions and the food commodity import substitution policy.

The theoretical base for this paper has become the works of the scientists dealing with the problems of the structural economic development at the macro level (Esteban, 2000; Herzog and Olsen, 1979; Kazinets, 1981; Krasilnikov, 1999; Sonis et al., 1996).

While conducting the research, the authors used the general economic methods (grouping, comparison, as well as economic and statistical methods) and special structural indicators:

- the mass and annual average speed of the changes in structural shifts - in order to study the efficiency of the structural shifts in the agrarian sector of the region (Krasilnikov, 2001; Russkova, 2017);

- index of structural shift (Knudsen, 2000) and share aggregates (Schmidt, 2015) to analyse the dynamics of the agrarian structure and the quantitative assessment of the structural shifts.

The structural shifts in some economies in the $21^{\text {st }}$ century are studied in the papers of (Dasgupta and Chakraborty, 2005; Datt, 2006; Kahrl and Roland-Horst, 2009; Zabelina and Klevakina, 2016). The research by J. Laitner (2000) constructs the model consisting of the industrial and agricultural sectors.

The modelling of the structural shifts is performed using econometric (factorial) models. Although the paper of $\mathrm{V}$. Marjanovic (2015) notes that the econometric approach to some extent simplifies the results of the structural analysis, we guess that this method is the most preferable for the achievement of the objectives of the paper. Application of econometric methods for conducting research is rather popular (Hasanli and Ismayilova, 2017) because such models are characterised by the presence of standard criteria indicators of their adequacy, the possibility of correct consideration of the modelled factors and convenience of implementation (Apokin et al., 2017). Moreover, we will use various indicators of the structural changes as the exogenous variables of the models.

The empiric base of the paper is the results of the authors' research of the structural shifts and structural reorganisation in the agriculture of Russia.

\section{Results and Discussion}

The analysis of the statistical information has shown positive economic viability indicators for the crop farming and animal husbandry production in the RF in 2000-2016; moreover, 
for the implementation period of the import substitution 'road map,' one may observe some growth in this indicator. However, the low economic viability of the animal husbandry production ( $8.6 \%$ averagely over the period) does not allow efficiently develop the branch.

\section{Analysis of the Structural Shifts in the Russian Agriculture}

To define an efficient goods producer from the perspective of the import substitution policy implementation, it is interesting to analyse the structural changes in the production of the most important kinds of agrarian produce across the main categories of the land users, paying special attention to the animal husbandry.
In the agriculture of modern Russia, there are three main categories of land users: agricultural organisations (AO), peasant (farm) enterprises $(P(F) E)$ and farm households. Our further research is based exactly on these three groups of goods producers (Akhmetshin et al., 2018).

So, the structural analysis of the shifts in the output of the main kinds of agricultural produce explicitly shows the problematical character of the situation in the dairy production and evidences the need of activating the import substitution program regarding the provision of the population with the dairy products made in Russia (Table 1).

Table 1: Analysis of the Structural Shifts in the Output of the Main Kinds of the Russian Agriculture Production in 2000-2016 (in brackets - the average ratio of the goods producers' group in the production structure, \%)

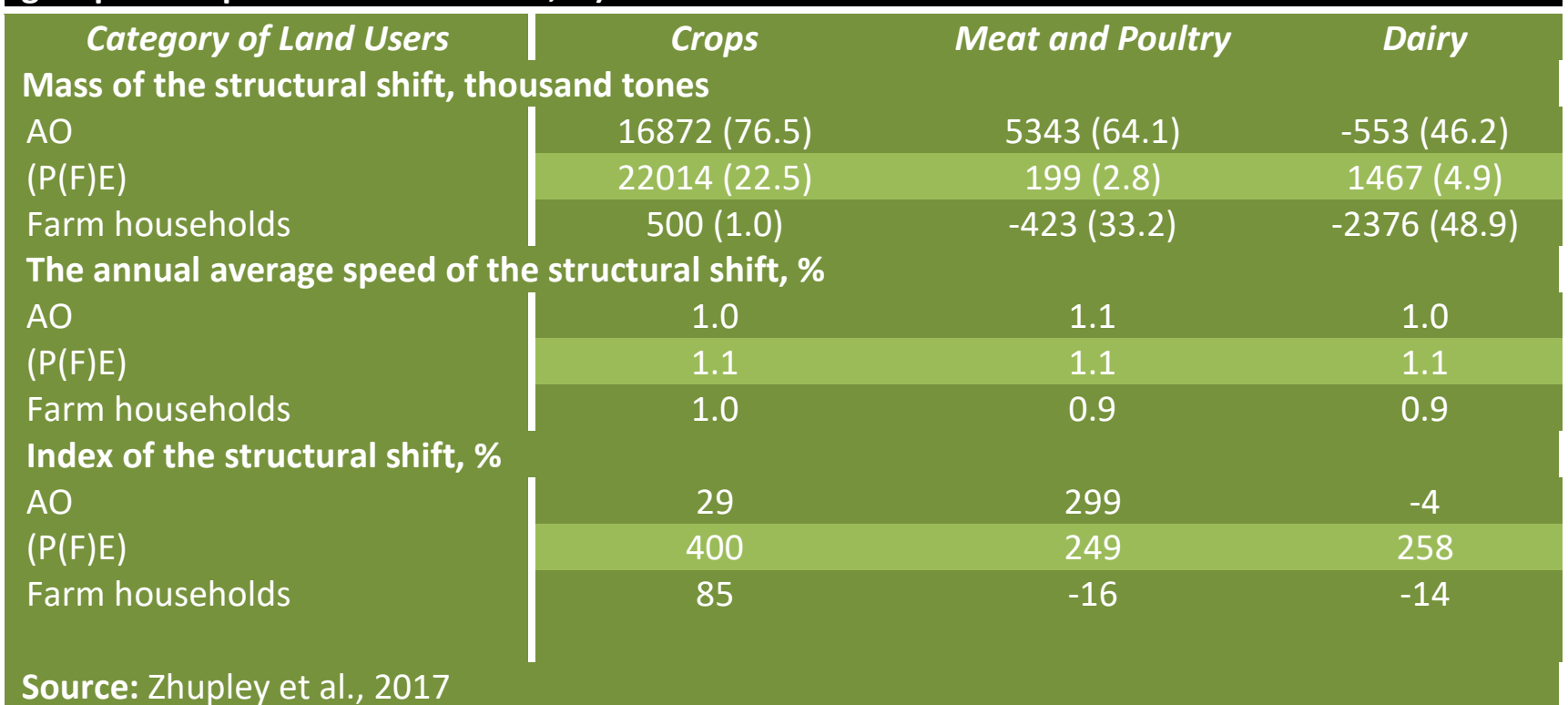

The 'dairy' structural shift may be characterised as positive only for the farming enterprises, but $(P(F) E)$ takes the last position in the hierarchy of the goods producers in the share of dairy production, lagging far behind the farm households and agricultural organisations.

In the production of meat, one should pay attention to the combination of the following indicators: the mass of the shift for the farm households (which is negative) and the share of this group of land users in the meat provision of the country in general (it is rather high and is equal to $33.2 \%)$. Such a combination of the structural characteristics also points at the desirable enhancement of the state's structural policy in the sphere of animal husbandry.

In the output of the crop, one may note high activity of the farmers, enhancing the production of this vital export culture four times.

\section{Analysis of the Import Substitution Policy Implementation (Success)}

The program of the food import substitution is first of all aimed at enhancement of the food security of the country. The problem of food security is world-wide (Gao, 2017). However, for Russia as for the state predominantly 
developing within the framework of the rawmaterials export model, it is significantly more acute.

The threshold values of the RF food sovereignty by the main crops produce been deemed achieved by this time. However, if the share of the foreign selection cultivars for many crops is equal to about $1-2 \%$, then for corn it is 43 , sunflower - 50, and for sugar beet, it is about 94\%. Interestingly, the Russian Federation presents at the world seed market predominantly as an importer. For instance, the correlation of import and export in the seed turnover in the PRC is 52:48, in the USA 46:54, in Canada - 41:59, while in Russia it is 97:3.

Moreover, to the RF the 'hybrid $F_{1}$ ' seeds are imported, which cannot be further reproduced. In the structure of production cost of potato, carrot and cabbage grown at the fields of large AO, approximately $75 \%$ accounts for the imported seeds, equipment, spare parts and other elements of the production process. While in the production cost of beet-root sugar, as (Blaginina, 2016) writes, the share of the imported component reaches $60 \%$.

One may observe 'successful' deterioration of the soil fertility: removal of nutrients from the soil almost three times exceeds their recovery due to the catastrophic decrease in fertilisation of the fields. By the current level of fertilisation per $1 \mathrm{ha}$, the RF fields three times lag behind Canada, five times - the US and India, seven times - Belarus, and ten times - China. The organic fertilisers are almost not applied to the soil. I. Buzdalov notes that "to the overwhelming area of the fields crop rotation, which is the most important element of the farming standards, is no longer applied", and the reclamation system of the agriculture has almost been destroyed (Buzdalov, 2016).

In the crop productivity, the RF still lags behind all the leading countries. So, average crop productivity of the crops in the world reaches 36 DT/ha (including France and the US - 70, in Germany - 67, in China - 55, in Finland and Canada - 35 DT/ha), while in Russia it is 20-22 DT/ha (Pavlova and Zhukovina, 2015).

So, the increment in the crop output (which is considered as a formal attribute of 'success' in solution of the import substitution problem in the agriculture sphere) is ensured due to serious imbalances in the structure of cultivated area, artificial 'fluxes' in planting of crops, sunflower, general disproportions between crop farming and animal husbandry. The 'negative' practice of the late 1920s - early 1930 s is being repeated, when the export of the crops had an adverse effect on the fodder supply of the animal husbandry, leaving even the peasants without food.

Within the frameworks of this research the authors computed the level of self-sufficiency of the state with the vital kinds of livestock products according to the following Equation:

Level $_{\text {self-sufficiency }}=100 \%-\frac{\operatorname{Im} \text { port } \cdot 100 \%}{\text { Stock }_{\text {beginningoftheyear }}+\operatorname{Production}+\operatorname{Im} \text { port }- \text { Stock }_{\text {endoftheye ar }}}$.

For illustrative purposes, these indicators are presented in Figure 1. 


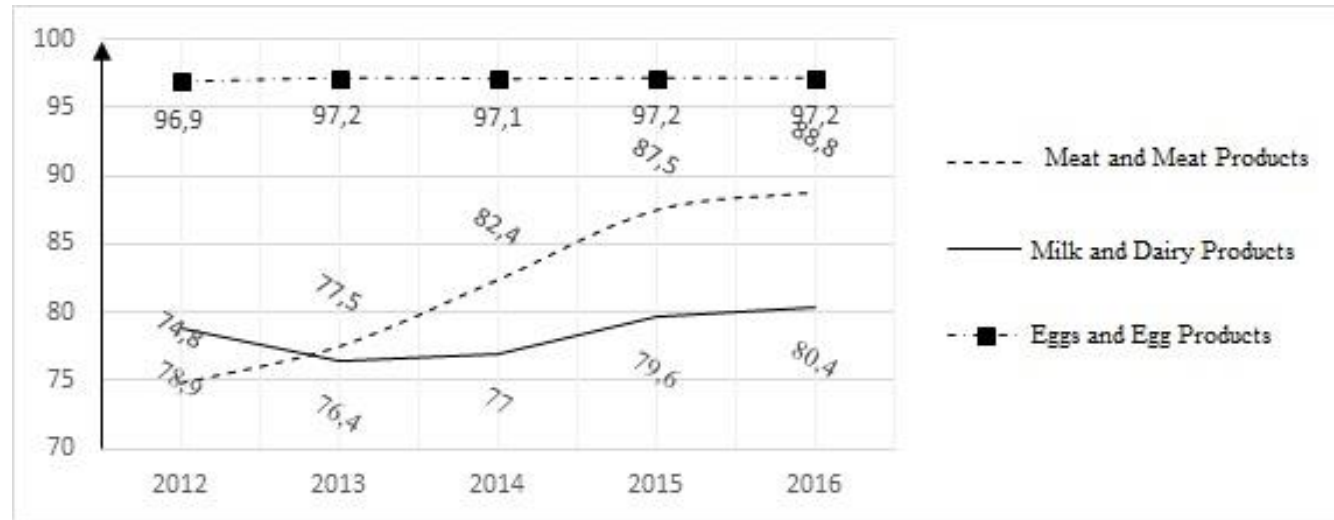

Figure 1: Dynamics of Self-Sufficiency with Livestock Products in Russia throughout 2012-2016 Source

One may note that the meat and egg products food sovereignty (the threshold for which in Russia is equal to $85 \%$ and $90 \%$ respectively) has been achieved. The $90 \%$ dairy 'standard' has not been achieved. However, the graph shows a rather stable trend of this indicator for growing.

Naturally, the growth in the self-sufficiency level indicators of the state with the most important kinds of livestock products is a positive moment of the import substitution policy implementation. However, there are many 'hidden pitfalls' the same as in the crop farming branch.

The pressing of the genetic pattern of the RF animal husbandry by the foreign animal husbandry gene pool provokes particular concern. Regarding the dairy breeding, it is manifested both in the mass 'holstainization' of the bovine cattle both in the direct import of the livestock and of the embryos. In the beef poultry and pork cattle breeding direct 'substitution' of the nationally bred animals by the imported livestock takes place. Moreover, thus, there is a high level of dependence on imported supplements, vaccines and veterinary preparations.

\section{Modelling of the Structural Shifts}

To reveal an efficient 'player' of the structural reconstruction of the agrarian sector of the Russian economy and the import substitution policy, the authors have built an econometric model of the several structural shifts influence on the productiveness of the RF agriculture.

In this model, the endogenic variable is the agriculture output growth in Russia ( $T$, \%), while as the exogenous variables there are the following structural characteristics:

- $I_{S}$ - index of the structural shift in the cultivated lands of the agricultural organisations (\%);

- $I_{N 1}$ - index of the structural shift in the number of farm households (\%);

- $I_{N 2}$ index of the structural shift in the number of farm enterprises (\%);

- $M$ - the mass of the structural shift in the agriculture output by the agriculture organisations (billion RUB).

Analytical Form of the Model:

$$
T=100.654-0.119 \cdot I_{S}+0.318 \cdot I_{N 1}-0.171 \cdot I_{N 1}+0.409 \cdot M \text {. }
$$

$$
\begin{array}{lll}
(0.002) \quad(-0.012) \quad(-0.01) \quad(0.023) & 0
\end{array}
$$

In brackets, there are coefficients of flexibility The constructed model correctly describes the for the corresponding factors, showing by what per cent the exogenous variable changes at the change of the corresponding factor by one per cent. process of formation and behaviour of the structural shifts in the agricultural sphere of modern Russia.

So, the correlation coefficient between the endogenic variable and the exogenous factors 
amounted to 0.995, which evidences a tight connection between the agricultural output growth rate and the highlighted structural characteristics. The average error of approximation is less than $1 \%$, which confirms the correct choice of the mathematics form of the model. The volume of the initial data massive, used at the modelling, is sufficient for revealing of the regularity in the process of the structural shift formation in the agricultural output by the main groups of land users, which is confirmed by the found values of the Fisher's ratio test.

The analysis of the flexibility coefficients of the presented model has shown that the real positive effect on the agriculture output growth may be taken by the agrarian organizations of various business structures, because the flexibility coefficients of the structural shift index in the cultivated lands of the agricultural enterprises and the mass of the structural shift in the output of the $A O$ are positive.

So, in Russia, these are exactly agricultural organisations that may contribute to the productivity of the import substitution policy and positively direct the structural reorganisation of the agricultural sphere, including the dairy cattle breeding.

The efficiency of the structural shifts, their transformation from the negatively to the positively directed is closely connected with the external and internal state policy, including in the context of the import substitution policy terms implementation.

Here one should pay attention to the following paradox. The World Trade Organization (WTO), where Russia joined in 2012 after decades of the negotiations, requires the loss recovery of the European farmers, caused by the Russian sanctions. So, the European Union (EU) imposed on the Russian Federation the requirement about charging $€ 1.4$ billion per year because of the pork import embargo (Zhukovsky, 2017).

As yearly as in 2016 the World Trade Organization decided that the Russian embargo on the supply of pork from the European Union is 'illegitimate'. According to the WTO, this step 'hit hard' the farm households of Denmark, the Netherland, and the FRG. At the end of summer 2017, the European Commission disclosed a series of documents stating that many subbranches of the EU agriculture were not able to recover after the Russian countersanctions forbidding the supply of their produce.

For the Russian government, it was challenging to smooth the adverse effect of the sanction war in the sphere of agricultural products for the population. For the dairy cattle breeding, it has not been achieved to the full extent.

One should remember that due to the agrarian reforms of the agriculture of the last two decades of the $20^{\text {th }}$ century many branches of the animal husbandry in the RF were categorised as 'redundant' and 'unproductive'. As a result, the cattle population in our country decreased from 57.0 million in 1990 to 19.1 in 2016.

Not always the priorities of the structural policy in the agriculture sector of the Russian economy are scientifically substantiated. So, alongside with the aspiration to the modernisation of the production capacities for the dairy products, rendering assistance in the investment for the increase in the output and productiveness of the farm households being the raw material supplier are reasonable.

However at the south-east of the country, 70\% of the dairy households are small producers, and even supported by the government, they are sceptical about large investments. One may suppose that the peasants will strive for the joint enlargement of the households, but due to the negative image of the socialists' agricultural organisations of the former Soviet Union, there are local peculiarities, complicating the formation of the livestock farms.

Over the years of the reforms, the structure of the Russian economy has significantly changed. The share of the agriculture decreased two times, as well as the share of the transport at the growth in the ratio of trade (Druzhinin and 
Prokopiev, 2015). Naturally, such a structure cannot be considered to be optimal.

The Russian economy of the last years is characterised by the growth in the effectiveness in the use of the resource potential, and formation of the new vital functional (including structural) connections. However, unfortunately, the scale of these processes does not allow 'breaking' the regularities, earlier established at the external markets (both financial and product). So, special attention according to V.V. Ivanter (2017) should be paid to the sectors with the growth potential from a short-term perspective (Ivanter et al., 2017). The agribusiness and agriculture, as its central link, is among such sectors. Moreover, the thesis "any growth of the agrarian production is undoubtedly good" is rather harmful than useful because the directives for the increase in performance indicators should be formulated from the perspective of the agrarian structure optimisation.

According to N.N. Mikheeva (2013), another aspect of the changes in the structural proportions is connected with the diversification of the regional economy. At the same time, the diversification of the production structure is considered not only as a vital direction of an innovative way of the Russian economic development but also as a basic development strategy of all the Russian regions.

\section{Conclusion}

The food import substitution is a vital problem of the agrarian policy that requires the integral system of solutions.

Import substitution in the sub-branches of the agriculture and food industry should be combined with the export development in the other spheres (based on the methodology of full and efficient use of the available agricultural potential). The import substitution in the agriculture cannot be achieved without the coordinated and priority development of the other branches of the national economy.
Structural changes in any sphere of a state's economy including its agrarian component, are successful only in case if:

- they lead to the equal benefit for the economic entities;

- they correspond with the progressive trends;

- they do not worsen the qualitative and quantitative indicators of the accompanying reforms.

Such a structural shift in the economic branches (including in the animal husbandry) will be effective, which will not only increase the general efficiency of the economy according to the parameters mentioned above but also decreases the positivism of the structural shifts connected with it and is ensured by the least possible expenses. Creation of the efficient structure of goods producers in the agriculture of the country requires the formation of the structural shifts of such a focus that will satisfy the social needs in the sphere of the food supply to the fullest possible extent.

The agricultural structure (the same as the structure of its livestock branch) will be deemed effective if the positively directed structural shifts initiate sustainable growth of the main indicators of the technological and economic efficiency according to all the groups of goods producers.

Insufficient rates of the positive structural shifts formation in the RF animal husbandry require activation of the import substitution policy in the context of stimulation of the agricultural organisations' production and commercial activities of various business forms.

\section{References}

Aganbegyan, A.G., Mikheeva, N.N., Fetisov, G.G. (2013). Modernization of the Real Sector of the Economy: Spatial Aspects, Regional Research of Russia, 3(4), pp. 309-323.

Akhmetshin, E., Danchikov, E., Polyanskaya, T., Plaskova, N., Prodanova, N., Zhiltsov, S. (2018). Analysis of innovation activity of 
enterprises in modern business environment. Journal of Advanced Research in Law and Economics, 8(8), pp. 2311-2323.

Apokin, A.Yu., Gnidchenko, A.A., Sabelnikova, E.M. (2017). Potential for Import Substitution and Benefits from Economic Integration: Disaggregated Estimates. Economic Policy, 12(2), pp. 44-71.

Arbuzov, S.G. (2017). Territorial Disproportions of Ukraine's Development and the Threats they Generate from the Loss of the Country's Economic Security, Modern Europe, 1(73), pp. 94-103.

Baynova, M.S., Kozyrev, M.S., Petrov, A.V. (2016). Correlation analysis of government influence on the selected aspects of Russian economy. Actual Problems of Economics, 182, pp. 334-343.

Bennett, T. (2008). The Soft Commodities you should Buy Now, Money Week's, Available at https://moneyweek.com/1195/the-softcommodities-you-should-buy-now/

Blaginina, I. (2016). Without Loans, the Land does not Bear Fruit, Russian Newspaper, 6599(28), Available at: https://rg.ru/2015/02/12/situaciya.html

Buzdalov, I. (2016). Scientific Bases and Modern Strategy of Agrarian Policy in Russia, AIC: Economy, Management, 3, 8-20.

Countrymeters. (2017). The Population of the Earth. Available at: https://countrymeters.info/ru

Danilov-Danilyan, V.I., Khranovich, I.L. (2010). Water Resources Management. Harmonization of Water Use Strategies. Moscow: Nauchnyy Mir.

Dasgupta, P., Chakraborty, D. (2005). The Structure of the Indian Economy. Paper presented at 15 International InputOutput Conference, organized by Renmin University, Beijing, China, June 27- July1, 2005. Available at: https://www.iioa.org/conferences/15th/ pdf/dasguptachakraborty.pdf
Datt, R. (2006). Emerging Structure of Indian Economy: A State-Wise Analysis, The Indian Journal of Labour Economics, 49(2), pp. 337-352.

Druzhinin, P.V., Prokopiev, E.A. (2015). Modeling of Sectoral Structural Shifts in the Russian Economy. Economic Analysis: Theory and Practice, 2015, 16(415), 2635.

Esteban, J. (2000). Regional Convergence in Europe and the Industry Mix: a ShiftShare Analysis, Regional Science and Urban Economics, 30(3), 353-364.

Gao, T. (2017). Food Security and Rural Development on Emerging Markets of Northeast Asia: Cases of Chinese North and Russian Far East. In V. Erokhin (ed.), Establishing Food Security and Alternatives to International Trade in Emerging Economies, Hershey, PA: IGI Global, pp. 155-176.

Hasanli, Ya., Ismayilova, S. (2017). Econometric Model of Dependence between the Oil Prices, and the Global External Debt Level and Oil Production, Economic Annals-XXI, 166(7-8), pp. 11-15.

Herzog, H.W., Olsen, R.J. (1979). Shift-share Analysis Revisited: The Allocation Effect and the Stability of Regional Structure, a Reply, Journal of Regional Science, 19(3), 393-395.

Ivanter, V.V., Blokhin, A.A., Borisov, V.N., et al. (2017). Structural and Investment Policy for the Modernization of the Russian Economy, Problems of Forecasting, 4(163), pp. 3-16.

Kahrl, F., Roland-Horst, D. (2009). Growth and Structural change in China's Energy Economy, Energy, 34(7), pp. 894-903.

Kazinets, L.S. (1981). Growth Rates and Structural Shifts in the Economy. Moscow: Ekonomika.

Knudsen, D.C. (2000). Shift-Share Analysis: Further Examination of Models for Description of Economic Change, Socio- 
Economic Planning Science, 34(3), 177198.

Korobeynikov, M.A. (2010). The Doctrine of Food Security in Russia: Problems of Implementation, Transactions of the Free Economic Society of Russia, 132, pp. 1014.

Krasilnikov, O. (1999). Structural Shifts in the Economy: Theory and Methodology. Saratov: Nauchnaya Kniga.

Krasilnikov, O. (2001). Problems of Structural Transformations in the Economy. Economist, 8, 52-58.

Laitner, J. (2000). Structural Change and Economic Growth, Review of Economic Studies, 67(3), pp. 545-561.

Manturov, D., Nikitin, G., Osmakov, V. (2016). Planning of the Policy of Import Substitution in the Russian Industry: the Practice of Russian Public Administration, Issues of Economics, 9, pp. 40-49.

Marjanovic, V. (2015). Structural Changes and Structural Transformation in a Modern Development Economy, Economic Themes, 53(1), pp. 63-82.

Mikheeva, N.N. (2013). Structural Factors of Regional Dynamics: Measurement and Evaluation, Spatial Economics, 1, pp. 1132.

Natuhara, K. (2008). Structural Change and Economic Growth: Evidence from Japan, Economic Bulletin, 15(9), pp. 1-11.

Naumenkova, S.V. (2015). Financial inclusivity: Economic contents and the approaches to its assessment. Actual Problems of Economics, 166(4), pp. 363-371.

Osipov, A.N., Hasanova, Kh. N., Veselovsky, M.Ya., Osipov, V.S., Gnezdova, Yu.V. (2018). Import Substitution in Agriculture: Crises of Overproduction, Choice of Institutional Policy, Application of Behavioral Economics, AIC: Economy, Management, 1, pp. 11-21.
Pavlov, P.N., Kaukin, A.S. (2017). Import Substitution of Investment Goods in Russia, Issues of Economics, 8, pp. 92-103.

Pavlova, G., Zhukovina, S. (2015). Import Substitution and the Market of Mineral Fertilizers. Russia, AIC: Economy, Management, 8, 53-58.

Povorina, E.V., Serbskaya, O.V., Bondaletova, N.F., Duplij, E.V., Buley, N.V. (2017). Improving quality control tools for domestic industrial production. International Journal of Applied Business and Economic Research, 15(12), pp. 283296.

Prilepsky, I. (2017). Factors of the Dynamics of Exports and Import Substitution after a Sharp Weakening of the National Currency, Economic Policy, 3, pp. 100133.

Russkova, E.G., Mitrofanova, I.V., Vatyukova, O.Yu., Ivanov, N.P., Batmanova, V.V. (2017). Structural Changes in the GDP of Russia in 1995-2015: Sectoral approach, Regional and Sectoral Economic Studies, 17(1), 39-54.

Ryabova, T.M. (2012). System of social support of citizens in Russia in the conditions of economic crisis. Materials of the Afanasiev Readings, 1(10), pp. 232-237.

Shmidt, Yu. D., Gu, E. (2017). Structural Changes in the Food Industry of Primorsky Krai, Russian Journal of Entrepreneurship, 7, pp. 1177-1192.

Shmidt, Yu.I. (2015). Method of Assessing the Effectiveness of Structure and Structural Changes in the Agricultural Sector of the Economy, Economics and Entrepreneurship, 3(56), 483-486.

Sonis, M., Hewings, G.J.D., Guo, J. (1996). Sources of Structural Change in InputOutput Systems: A Field of Influence Approach, Economic Systems Research, 8(1), 15-32.

Tsukhlo, S. (2016). Problems and Successes of Import Substitution in the Russian 
Industry, Journal of the New Economic Association, 4(32), pp. 147-153.

Ushachev, I. (2016). Scientific Problems of Import Substitution and Formation of Export Potential of Products of the AgroIndustrial Complex of Russia, AIC: Economy, Management, 1, pp. 4-21.

Zabelina, I., Klevakina, E. (2016). Structural Changes in the Economy of Cross-Border Regions of Russia and China, International Journal of Economics and Financial Issues, 6(4), pp. 1460-1467.
Zhukovsky, I. (2017). The Requirements of the EU are Lawlessness. Gazeta.ru. Available at:

https://www.gazeta.ru/business/2018/01 /07/11596256.shtml

Zhupley, I.V., Potenko, T.A., Grafov, R.A. (2017). Analysis of Structural Shifts in the Context of Solving the Import Substitution Problem, The Economics of Agriculture in Russia, 8, pp. 55-61. 